\title{
Problems of postgraduate students including school principals, teachers and inspectors in educational sciences $^{*}$
}

\author{
Funda NAYIR ${ }^{* *}$
}

\begin{abstract}
The aim of this research is to find out the opinions of the postgraduate students who are studying in the field of educational sciences towards the problems they have encountered. Research sample composed of 98 teachers, 13 school principals and, 3 inspectors who had been attended postgraduate courses at least one semester and also at the module taking stage from the four universities, namely Ankara, Hacetepe, Gazi and Middle East Technical University. This is a descriptive survey and the data were gathered by a questionnaire developed by the researcher called "Problems of Postgraduate Students Including School Principals, Teachers and Inspectors in "Educational Sciences". In research frequencies, percentages, arithmetic mean, standard deviation, t-test, LSD test, One-Way ANOVA and Mann Withney-U test were used.
\end{abstract}

Keywords: Postgraduation, educational sciences, teacher, school princpals, inspectors, problems.

\footnotetext{
This study is a summary of master of art thesis, "Problems of Postgraduate Students Including Teachers, School Principals and Inspectors in Educational Sciences", studied with supervisor Prof. Dr. İnayet Pehlivan Aydın and presented at Institute of Educational Sciences, in September, 2007.

** Ph D. Student, Ankara University, Institute of Educational Sciences, E-mail: fnayir@yahoo.com
} 


\section{SUMMARY}

The aim of this research is to find out the opinions of the postgraduate students who are studying in the field of educational sciences towards the problems they have encountered

Research sample composed of 98 teachers, 13 school principals and, 3 inspectors who had been attended the Master of Art and Doctor of Philosophy courses at least one semester and also at the module taking stage from the four different universities, namely Ankara University, Hacetepe University, Gazi University and Middle East Technical University.

This is a descriptive survey and the data were gathered by a questionnaire developed by the researcher called "Problems of the Postgraduate Students Including school Principals, Teachers and Inspectors in the field of Educational Sciences" The questionnaire has three dimensions including the "problems stemmed from the Postgraduate Education Institutions", "Problems stemmed from the Ministry and schools", and "Problems stemmed from personal, social and economical factors". During the analysis of the data gathered by the questionnaire Statistical Package for Social Sciences (SPSS) was used. With regard to personal information of school principals, teachers and inspectors frequencies, percentages and were given and also the arithmetic mean and standard deviation was found. In order to find out whether or not the opinions of school principals, teachers and inspectors related to problems encountered differs the t-test, LSD test, One-Way ANOVA and Mann Whitney-U test were used.

University found to be having more problems than those were registered at Hacettepe University, Gazi University and Middle East Technical University. In addition the participant attending Educational Physiology found to be having more problems than those were attending at Educational Management Supervision, Economics and Planning and Educational Programme and Instruction. When looked at the work experiences of the participants, those who have six or over six years experience in the profession seems to have more problems than other groups. As far as the type of the programme, task, sex and age variables are examined; all the groups seem to have similar opinions about the problems they have encountered.

As far as the dimensions of Ministry and school; personal, economical, and social factors are concerned it has not been found any significant differences taking into account the research variables. 


\title{
Eğitim Bilimleri Alanında Lisansüstü Öğrenim Görmekte Olan Müfettiş, Okul Yöneticisi ve Öğretmenlerin Sorunları*
}

\begin{abstract}
Funda NAYIR*
ÖZ. Lisansüstü öğretim lisans eğitiminden sonra bireylere ilgi duydukları alanda araştırma yapmayı ögreten, bilim üreten ve bilim insanı yetiştirmeyi amaçlayan bir eğitim programıdır. $\mathrm{Bu}$ çalışmanın amacı Eğitim Bilimleri alanında lisansüstü öğrenim görmekte olan öğretmen, yönetici ve müfettişlerin karşılaştıkları sorunlara ilişkin görüşleri ortaya çıkarmaktır. Araştırmanın çalışma grubunu Ankara Üniversitesi, Gazi Üniversitesi, Hacettepe Üniversitesi ve Orta Doğu Teknik Üniversitesi'nde Eğitim Bilimleri alanında lisansüstü öğrenim görmekte olan ve ders aşamasının en az bir dönemini tamamlamış öğretmen yönetici ve müfettişler oluşturmaktadır. Araştırma tarama modelinde olup veriler "Eğitim Bilimleri Alanında lisansüstü Öğrenim Görmekte Olan Öğretmen, Yönetici ve Müfettişlerin Sorunları" ölçeği ile toplanmıştır. Araştırmada, analizler için aritmetik ortalama, standart sapma, t-testi, LSD testi, varyans analizi ve Mann Withney-U testi kullanılmıştır.
\end{abstract}

Anahtar Sözcükler: : Lisansüstü, eğitim bilimleri, öğretmen, okul yöneticisi, müfettiş, sorunlar.

\footnotetext{
* Bu çalışma Prof. Dr. İnayet Pehlivan Aydın danışmanlığında yürütülen ve Eylül 2007 tarihinde Ankara Üniversitesi Eğitim Bilimleri Enstitüsüne sunulan “Ankara'da Eğitim Bilimleri Alanında Lisansüstü Öğrenim Görmekte Olan Öğretmen, Yönetici ve Müfettişlerin Karşılaștıkları Sorunlar” isimli yüksek lisans tezinin özetidir.

** Doktora Öğrencisi, Ankara Üniversitesi Eğitim Bilimleri Enstitüsü, E-posta: fnayir@yahoo.com
} 


\section{GíRIȘ}

Bireyin içinde bulunduğu çevre sürekli değişmektedir. Bu nedenle birey bu değişime uyum sağlamak ve bu değişimleri takip etmek zorundadır. Bireylerin bulunduğu çevrenin ve yaşam şartlarının değişmesi ve bu değişimin bilgiye dayanması bireylerin öğrenmeye olan ihtiyaçlarının artmasına neden olmuş bunun sonucunda bilgi toplumu ve yaşam boyu eğitim kavramları ortaya çıkmıştır (Erkan, 1998, 125).

Bilgi toplumu, toplumda her türlü bilgiyi üreten, bilgi ağlarına bağlanan, hazır bilgilere erişen, erişilmiş bilgileri kolaylıkla yayabilen ve bilgileri her sektörde kullanan (ekutup.dpt.gov.tr/bilim/), bilginin gerçek sermaye ve zenginlik kaynağı haline geldiği (Özden, 2002, 76) ve bilgiyi yalnız alıp kullanan değil; üreten ve sorunların çözümünde kullanabilen toplumdur (Oğuz, 2004).

$\mathrm{Bu}$ tanımlardan yola çıkarak bilgi toplumunu, teknolojik gelişmeleri takip etmek, bilgi üretmek ve üretilen bilgiyi kullanmak için nitelikli insangücüne ihtiyaç duyulan, bu insangücünü karşılamak için de eğitimin süreklilik kazandığ 1 bir toplum yapısı olarak tanımlamak mümkündür. $\mathrm{Bu}$ tanıma göre bilgi toplumunu oluşturacak bireyler; çok yönlü düşünen, olaylara eleştirel bakabilen, yaratıcı, üretken, problem çözme gücü yüksek özellikler taşımalıdır (Özden, 2002, 77). Eğitim sisteminin bu ihtiyaçlara cevap verebilmesi için yeniden düzenlenmesini gerekir. Bunun için hazırlanacak eğitim programında bilgiyi temel olarak alan bir eğitim programı uygulanmalıdır. Ayrıca serbest düşünen, tartışabilen bir toplumun oluşturulmasına çalışılmalı ve eğitimde çocuklara daha fazla düşünme, tartışma ve araştırma ortamı sağlanmalıdır. Yetişkinlerin eğitimi ve teknolojiye adaptasyonuna yönelik yaşam boyu eğitim programları hazırlanıp uygulanmalıdır (ekutup.dpt.gov.tr/bilim/).

Yaşam boyu eğitim, toplumun yeni oluşumlara ve toplumdaki farklılıklardan ortaya çıkan değişimlere uyum sağlamasında bir çeşit rehber görevi görmektedir ( www.eurydice.org). Yaşam boyu eğitim teknolojik ve toplumsal değişmelere ayak uydurabilmek, bireysel gelişimi desteklemek için bireylere zorunlu eğitim dışında verilen eğitim sürecidir (Geray, 2002, $6,9)$.

Görüldüğü gibi, bilgi toplumu ve yaşam boyu eğitim kavramları birbiriyle bağlantılı kavramlardır. Bilgi toplumunun sonucu olarak ortaya çıkan yaşam boyu eğitim kavramı, günümüzde bütün toplumların ihtiyaç duyduğu eğitim haklarından biri olarak görülmektedir.

Bilginin hızla arttığı bir ortamda, bilginin üretilmesi ve bilginin tüketilmesi büyük önem taşımaktadır. Bilgi çağı, bireylerin, bilgiyi yalnız alıp kullanmalarını değil; üretmelerini, sorunların çözümünde 
kullanabilmelerini gerektirmektedir (Oğuz, 2004). Bilginin üretilmesi, öğretilmesi ve yayılmasında da eğitim sistemine büyük görevler düşmektedir (Karakütük, 2002a). Eğitim sisteminin en üst düzeyinde yükseköğretim bulunur. Üniversiteler yükseköğretim hizmeti veren eğitim kurumlarıdır. Üniversiteler, işlevlerini içinde bulundukları çağın değişme ve gelişmelerine paralel olarak yerine getirirlerse çağdaş bir toplum oluşmasına katkıda bulunabilirler (Oğuz, 2004).

Fransizca'da "education post-universitaire", İngilizce'de "postgraduate education" veya "quaternary education" Kuzey Amerika'da "graduate education" olarak kullanılan (en.wikipedia.org) lisansüstü öğretim kavramı üniversiteyi bitirdikten sonra verilen araştırma eğitimi veya uzmanlaşma eğitimi olarak tanımlanmakta ve özellikle doktora derecesinde araştırma yapabilmek için bir staj süresi olarak görülmektedir (OECD, 1987).

Lisansüstü öğretim, çağdaş üniversitenin önemli bir işlevidir. Özellikle ülke sorunlarına yönelik araştırma yapmada ve ülkenin gereksinim duyduğu yüksek nitelikli insangücünü yetiştirmede lisansüstü öğretim büyük önem taşımaktadır (Karakütük, 2002b, 65).

Arıc1 $(2001,56)$ lisansüstü öğretimin işlevlerini bilim/sanat üretmek ve yaymak, toplumsal sorunları doğru algılamak ve çözüm önerileri geliştirmek, üst düzey insangücünün yetiştirilmesine katkıda bulunmak olarak belirtmiştir. Bütün bu açıklamalardan lisansüstü öğretimin insangücü kaynağının yetiştirilmesinde ve toplumun gelişmesinde önemli bir katkısı olduğunu söylenilebilir.

Lisansüstü öğretim, araştırma yoluyla bilime katkıda bulunacak ve toplum ihtiyaçlarını karşılayabilecek bilim insanı ve öğretim elemanı yetiştiren (Varış, 1972); "lisans eğitiminden daha üst seviyede bilgi ve etkinliğe sahip yüksek ihtisas gücünü yetiştiren " (Çakar, 2001); lisans diploması almış olanlara ilgi duydukları bir bilim dalında yüksek lisans (bilim uzmanlığı) ya da doktora öğrenimi yaparak uzmanlaşma olanağı sağlamak üzere verilen (Oğuzkan, 1981) araştırma yapabilen, üretken, ülke sorunlarına duyarlı, yaratıcı bireyleri yetiştiren bir öğretim programıdır (Sayan ve Aksu, 2005). Bu tanımlardan yola çıkarak lisansüstü öğretimin lisans eğitiminden sonra bireylere ilgi duydukları alanda araştırma yapmayı öğreten, bilim üreten ve bilim insanı yetiştirmeyi amaçlayan bir eğitim programı olduğu söylenebilir.

Lisansüstü öğretim ülkelerin hedeflerini gerçekleştirmede iki yönden katk1 sağlar. Bunlardan birincisi yükseköğretim kurumlarının ihtiyaç duyduğu insangücünü yetiştirmesi ikincisi ise ülkelerin ekonomik, teknolojik ve kültürel sorunlarına çözüm getirmesidir (Tosun, 2001). Toplumun gereksinimi olan, özellikle yükseköğretimde ve bilimde seçkinler, gelişmiş üniversitelerdeki doktora programlarıyla yetiştirilebilmektedir. 
Lisansüstü öğretim, yükseköğretimde öğretim ve araştırma bütünlüğünü daha kuvvetli hale getiren ve sürdüren bir bağdır. Lisansüstü programlar ve özellikle doktora programlarıyla; kişilere bağımsız araştırma yapma, bilimsel olayları geniş ve derin bir bakış açısı ile irdeleyerek yorumlama ve yeni sentezlere ulaşma yeteneği kazandırılmaktadır (Tuzcu, 2003).

Eğitim bir ülkenin kalkınmasında ve gelişmesinde önemli rol oynayan, ülkelerin geleceğini belirleyen, insanların çağa ayak uydurmasını sağlayan bir süreçtir (Acar, 2002). Ataünal'a (2002) göre bu sürecin sağllklı olabilmesi için bilim üretmek, yüksek kalitede insangücüne sahip olmak için bilimsel düşünme ve araştırma becerisi kazandırıcı, yeniliklere açık bir eğitim anlayışının esas olması gerekir. Bu anlayışın gerçekleştirilmesi için öncelikle öğretmenlerin bilimsel düşünebilen, yeniliklere açık, zihinsel tutum ve süreçleri iyi bilen ve bütün bunları çocuklara aktarabilen kişiler olması gerekir. $\mathrm{Bu}$ nedenle öğretmen yetiştiren kurumların eğitim programlarının bu anlayışa uygun olası gerekir.

Öğretmenlik 19. Yüzyılın başından beri meslekleşmeye çalışan bir alandır. İyi bir öğretmen olmak için iyi bir eğitim almakla birlikte çağın gereklerini de karşılamak gerekmektedir. Değişimin önemli kurumlarından biri olan öğretmenlik ve öğretmenlerin rolleri de günümüzde hiçbir zaman olmadığı kadar farklılaşmıştır (Güven, 2001). Geleceğin öğretmenleri, yeniliklere açı, kaynak arayan, sorunları saptayabilen ve bu sorunlara çözüm önerileri getirebilen, bilimsel düşünebilen, insan ilişkileri kuvvetli, mesleki gelişime açık, öğrencilere rehberlik yapabilen (Özgüven, 1997), kendi gelişimlerinden sürekli bir şeyler öğrenen, sorunları çözebilen, çağa ayak uydurabilen kişiler olabilmesi için sürekli mesleki gelişim içersinde olan (Calderhead, 1995) ve kendisiyle sürekli yarış halinde olan, yeni bilgi ve becerilerin peşinden koşan (Fındıkçı, 2001) kişilerdir.

Eğitim örgütlerini amaçlarına ulaştırmak için insangücü ve diğer kaynakların etkili kullanılması gerekir. Eğitim sisteminin başarılı olması eğitim yöneticilerinin yönetim alanında iyi yetişmesine bağlıdır (Acar, 2002a). Yönetim, amaçlara ulaşmak için kaynakların bütünleştirilmesi ve eşgüdümlenmesi (Hersey ve Blanchard, 1982, 3) amaçlara ulaşmak için kaynakların planlanması, örgütlenmesi, yönlendirilmesi ve kontrol edilmesi (Schermerhons, 1996, 13) olarak tanımlanmıştır.

$\mathrm{Bu}$ tanımlardan yola çıkarak yönetim belirlenen amaçlara ulaşmak için tüm kaynakların planlı, etkili ve verimli kullanılması şeklinde tanımlanabilir. $\mathrm{Bu}$ nedenle eğitim yöneticilerinin bilim ve teknolojik gelişmelere uyum sağlayabilmesi, kişisel ve toplumsal sorunlara cevap verebilmesi (Balcı ve Çınkır, 2002), kaynaklarını verimli kullanabilmesi gerekir.

Günümüz okulları velilerin katılımı, personel gelişimi, teknoloji, kaynakların kullanımı gibi sorunlarla uğraşmak zorundadır. Bu sorunların 
çözülebilmesi için okul yöneticilerinin yeterli becerilere sahip olması gerekir (Thomson, 1992, 7).

Yönetim süreçlerinden birisi olan denetim, planlanan örgütsel amaçlardan sapmayı önlemek için örgütün işlemesini izleme ve düzeltme sürecidir (Başaran, 2000, 137). Bursalığlu (2000, 172) denetimi, kamu yararına davranışları kontrol etme süreci olarak tanımlarken, Aydın (2000, 11) denetimi örgütsel eylemlerin saptanan amaçlar doğrultusunda kabul edilen ilke ve kurallara uygun olup olmadığının belirlenmesi süreci olarak tanımlamakta, denetimin temel amacını ise örgütün amaçlarının gerçekleştirilme düzeyini saptamak ve daha iyisini elde etmek için süreci geliştirmek olarak belirtmektedir.

Denetimin bu tanımları genel olarak kurumlardaki teftiş birimleri ve müfettişlerin görev alanlarını kapsamaktadır. Eğitim sisteminde müfettişlerin görevlerini gerçekleştirebilmeleri için gerekli yeterlikleri kazanmış olmaları gerekir. Müfettişte göreve ilişkin teknik bilgi, beceri ve tutumlara yönelik teknik yeterlikler; birey ve grupları anlama ve güdüleme becerileri olarak insancıl yeterlikler; yapılacak çalışmaları planlama, karşılaşılan sorunlara çözüm yolu bulma ve amaçlara ulaşma derecesi hakkında yargıya varma süreci olarak karar verme yeterlikleri olması gerekir (Taymaz, 2005, 36, 49).

Öğretmen, yönetici ve müfettişlerin tüm bu becerileri kazanmasında lisansüstü öğrenimin önemi büyüktür. Ancak öğretmen, yönetici ve müfettişlerin lisansüstü öğrenimi bu kadar önemli olmasına rağmen bu konu pek fazla araştırılmamıştır. Konuyla ilgili olarak Karakütük'ün (2000) yaptığı araştırmada öğretmen ve yöneticilerin en önemli gördükleri ilk üç sorun; lisansüstü öğrenimini tamamlayanlara verilen maddi karşıllı̆̆ın yeterli olmaması, bakanlıkça lisansüstü öğreniminin öneminin yeterince anlaşılamaması ve bakanlığın öğretmenlerin lisansüstü öğretimleriyle ilgili açık bir politikasının olmamasıdır. Araştırmada sorulan "Öğretmenlerin lisansüstü öğrenimlerine ilişkin var olduğunu düşündüğünüz diğer sorunları lütfen yazınız" biçiminde sorulan açık uçlu soruya verilen cevaplarda en çok belirtilen sorun "Öğretmenlerin ekonomik sorunları lisansüstü öğrenim yapmasına engeldir" olmuştur. Bu konuda belirtilen diğer iki önemli sorun "lisansüstü öğrenim yapan öğretmenlere Bakanlık, İl Milli Eğitim Müdürlüğü ya da çalıştığı okulda izin ve destek verilmemesi" ve "lisansüstü öğrenim yapan öğretmenlerin tayinlerinin yapılmasında engel çıkmasıdır."

$\mathrm{Bu}$ alanda yapılan bir başka araştırma Doğusan (2003) tarafindan yapılmıştır. Araştırmada, Karakütük'ün (2000) yaptığı araştırma sonuçları ile benzer sonuçlara ulaşılmıştır. Araştırma sonuçlarındaki ilk üç sorun lisansüstü öğrenimini tamamlayanlara verilen maddi karşıllı̆̆n yeterli olmaması, bakanlıkça lisansüstü öğretime gerekli önemin verilmemesi, öğretmenlerin lisansüstü öğretimin önemini anlamamasıdır. 
Her iki araştırmada çıkan ortak sonuçları ekonomik ödüllendirmenin yetersizliği, eğitime devam etmek için izinin verilmemesi, lisansüstü öğrenimin bakanlık ve öğretmenler arasında tam olarak anlaşılamaması olarak özetlenebilir. Bu iki araştırma öğretmen ve yöneticilerin lisansüstü öğrenim konusundaki görüşlerini öğrenmek için yapılmış, ancak müfettiş boyutu ve halen lisansüstü öğrenimine devam etmekte olan öğretmen, yönetici ve müfettişlerin bu eğitimlerini sürdürürken karşıllaştıkları sorunlar ele alınmamıştır.

Başer, Narlı ve Günhan'ın (2005) lisansüstü eğitim alan öğretmen adaylarının sistemden beklentilerini ve yaşadıkları sorunları ortaya çıkarmak amacıyla yaptıkları araştırmada öğretmenlerin büyük çoğunluğu lisansüstü programlarda öğrendikleri bilgileri sinıfta uygulayabildiklerini, öğretmen arkadaşlarıyla paylaşabildiklerini ve tezli lisansüstü eğitimin her öğretmen tarafından alınması gerektiğini belirtmişlerdir.

Benzer şekilde Oluk ve Çolak tarafindan (2005) yapılan araştırma sonucunda öğretmenlerin lisansüstü eğitime devam edebilmek için yasal olarak tanınan izin hakkından yararlanamadıkları MEB'nın lisansüstü eğitim için mali bir destek sağlamadığı ve Lisansüstü Eğitimin kayda değer bir gelir artışı sağlamadığı, öğretmenlerin atamalarının yüksek lisans öğrenimi görülen ile gecikmeli de olsa yapıldığı ancak stajyer memur olanların atama için engel oluşturması nedeniyle lisansüstü eğitim haklarını dondurdukları sonuçları ortaya çıkmıştır.

$\mathrm{Bu}$ iki araştırmada öğretmen ve yöneticilerin sorunları incelenmiş ancak örneklem grubuna müfettişler dahil edilmemiştir. Ayrıca örneklem grubu olarak Ankara dışında ki iller ele alınmıştır. Özdem, Bülbül ve Güngör'ün (2002) yaptığı araştırma sonucunda; programda yer alan ders sayısının fazla olduğu, öğrencilerin ders içeriğini bilmemelerinin, ders seçimini rastlantıya bıraktığı, öğrencilerin derslerin kredilerini az buldukları, ders saatlerinin öğrencilerin çalışma saatleri göz önüne alınarak planlanmadığı, bakanlık ve okul yöneticilerinin programa devam edebilmek için gereken yardımı göstermediği ortaya çıkmıştır. $\mathrm{Bu}$ araştırma sadece "Eğitim Yönetimi Planlaması Teftişi ve Ekonomisi Anabilim Dalı Tezsiz Yüksek Lisans Programına Devam Eden Öğretmen ve Okul Yöneticilerinin Programa İlişkin Görüşleri”ni ortaya çıkarmak için yapılmıştır.

Meydan'ın (1994) yaptığı araştırma sonucunda ortaya çıkan başlıca sorunlar yüksek lisans ve doktora öğrencileri lisansüstü programı için tanınan süreyi özelliklede tez süresini yetersiz bulmaktadır. Öğrencilerinin çoğunluğu sosyal gereksinmelerini zaman ve kaynak buldukları ölçüde karşıladıklarını belirtmişlerdir. Ancak öğrencilerin karşılamakta rahatsızlık duydukları bir gereksinim kültürel etkinliklere katılamamaktır. Doktora öğrencileri için ailelerine zaman ayıramamaları bir sorun oluşturmaktadır. Bu araştırmada 
"Ankara Üniversitesi Sosyal Bilimler Enstitüsüne Kayıtlı tüm Lisansüstü Öğrencilerin Sorunları" ele alınmış öğretmen, yönetici ve müfettişler olarak bir karşılaş̧ırma yapılmamıştır. Belirtilen araştırmalar incelendiğinde, öğretmen ve yöneticilerin lisansüstü öğretim surasında karşılaştıkları sorunların lisansüstü öğretim programlarından, Bakanlıktan, çalıştıkları okuldan, sosyal ve ekonomik faktörlerden kaynaklandığ 1 görülmektedir. Bu doğrultuda, bu çalışmada öğretmen, yönetici ve müfettişlerin lisansüstü öğrenimlerinde karşılaştıkları sorunların üç başlık altında toplanması araştırmacı tarafindan uygun görülmüştür. Bu sorunlar,

1. Üniversitelerden ve lisansüstü Öğretim programlarından kaynaklanan sorunlar,

2. Bakanlık ve okuldan kaynaklanan sorunlar,

3. Sosyal ve ekonomik faktörlerden kaynaklanan sorunlardır.

Yukarıda yapılan açıklamalardan ve incelenen araştırmalardan öğretmen, yönetici ve müfettişler için lisansüstü öğretimin önemli olduğu ancak bu öğretimlerini devam ettirirken üniversitelerden ve lisansüstü programlardan, bakanlık ve bağlı bulundukları okuldan ve sosyal ve ekonomik faktörlerden kaynaklanan sorunlarla karşılaştıkları sonucuna varılabilir. Araştırmalarda eğitim sistemi içerisinde yer alan öğretmen ve yöneticiler ele alınmış ancak sistemin amaçlarını gerçekleştirmesinde önemli bir role sahip olan müfettişler göz ardı edilmiştir.

$\mathrm{Bu}$ araştırmanın problemini Ankara'da eğitim bilimleri alanında lisansüstü öğrenim görmekte olan müfettiş, okul yöneticisi ve öğretmenlerin bu öğrenimlerini sürdürürken karşılaştıkları sorunlara ilişkin görüşleri oluşturmaktadır.

\section{Amaç}

$\mathrm{Bu}$ araştırmanın genel amacı Ankara'da eğitim bilimleri alanında lisansüstü öğrenim görmekte olan müfettiş, okul yöneticisi ve öğretmenlerin bu öğrenimlerini sürdürürken karşılaştıkları sorunlara ilişkin görüşleri ortaya koymaktır. Araştırmada genel amaçlar doğrultusunda aşağıdaki sorulara cevap aranmıştır.

1. Üniversitelerdeki lisansüstü programlardan kaynaklanan sorunlara ilişkin müfettiş, yönetici ve öğretmenlerin toplam kredi, toplam ders sayısı, derse devam zorunluluğu, ders saatleri, derslerde kullanılan ölçme ve değerlendirme yöntemleri konularındaki görüşleri nelerdir?

2. Müfettiş, yönetici ve öğretmenlerin lisansüstü programlardan kaynaklanan sorunlara ilişkin görüşleri arasında yaş, cinsiyet, kıdem, görev, üniversite, öğrenim görülen alan değişkenleri açısından anlamlı bir fark var midir? 
3. Bakanlık ve okuldan kaynaklanan sorunlara ilişkin müfettiş, yönetici ve öğretmenlerin izin, ders programı, çalışılan kurumun uzaklığı, lisansüstü öğrenime destek, lisansüstü öğrenimin önemi konularındaki görüşleri nelerdir?

4. Müfettiş, yönetici ve öğretmenlerin bakanlık ve okuldan kaynaklanan sorunlara ilişkin görüşleri arasında yaş, cinsiyet, kıdem, görev, üniversite, öğrenim görülen alan değişkenleri açısından anlamlı bir fark var mıdır?

5. Kişisel ve sosyal faktörlerden kaynaklanan sorunlara ilişkin müfettiş, yönetici ve öğretmenlerin ekonomik, ailevi, zaman, kişisel sorunlar konularındaki görüşleri nelerdir?

6. Müfettiş, yönetici ve öğretmenlerin kişisel ve sosyal faktörlerden kaynaklanan sorunlara ilişkin görüşleri arasında yaş, cinsiyet, kıdem, görev, üniversite, öğrenim görülen alan değişkenleri açısından anlamlı bir fark var midır?

\section{Sinırlılıklar}

Araştırma, Ankara'da bulunan Orta Doğu Teknik Üniversitesi (ODTÜ), Ankara Üniversitesi, Hacettepe Üniversitesi ve Gazi, Üniversitesi'nde Eğitim Bilimleri alanında lisansüstü öğrenim görmekte olan, ders aşamasının en az bir dönemini tamamlamış ilköğretim müfettişi ve resmi ilköğretim okullarında görevli yönetici ve öğretmenlerle sınırlıdır.

\section{YÖNTEM}

$\mathrm{Bu}$ bölümde araştırmanın modeli, çalışma grubu, veri toplama aracı ve verilerin çözümlenmesi konularına yer verilmiştir.

\section{Araştırmanın Modeli}

Araştırmada Ankara'da Eğitim Bilimleri alanında lisansüstü öğrenim görmekte olan müfettiş, okul yöneticisi ve öğretmenlerin bu öğrenimlerini sürdürürken karşılaştıkları sorunlara ilişkin görüşleri saptanmıştır. Araştırma var olan durumu ortaya çıkarmaya çalıştı̆̆ ve grupları birbirleriyle karşılaştırdığ 1 için araştırmada karşılaştırma türünde tarama modeli kullanılmıştır.

\section{Çalıșma Grubu}

$\mathrm{Bu}$ araştırmanın çalışma grubunu Ankara Üniversitesi, Gazi Üniversitesi, Hacettepe Üniversitesi ve Orta Doğu Teknik Üniversitesi'nde 
Eğitim Bilimleri alanında yüksek lisans ve doktora yapan, en az bir dönem devam etmiş ders aşamasındaki öğretmen, yönetici ve müfettişler oluşturmaktadır. Ancak üniversitelerde öğrenci kayıtları tutulurken meslek bilgilerine yer verilmediğinden üniversitelerde kayıtlı öğretmen, yönetici ve müfettiş sayıları kesin olarak tespit edilememiştir. Bu nedenlerle araştırma aracı ulaşılabilen toplam 113 öğrenciye uygulanmıştır.

Katılımcıların \% 47.6'si 26-30 yaş aralığında, \% 10.1'i 36 yaş ve üzerindedir. Buradan gençlerin lisansüstü öğrenime daha istekli olduğu sonucu çıkarılabilir. Gençlerin kendilerini geliştirmeye daha açık olması ve görevde yükselmeyi istemesi bunun nedeni olarak düşünülebilir. Katılımcıların \%58,4'ü kadın, \% 41,6'sı erkektir. Bu durum kadınların bu alanda kendilerini geliştirmeye daha çok ihtiyaç duyduğunu göstermektedir. Çünkü erkekler yönetim kademelerinde daha kolay yer alırken kadınların bu kademelerde yer alması için bu alanda uzman olduklarını kanıtlaması gerekmektedir. $\mathrm{Bu}$ nedenle kadınlar kariyer sahibi olmak için lisansüstü öğrenime ihtiyaç duyuyor olabilir. Katılımcıların çoğunluğunun meslekteki kıdeminin 1 ile 5 yıl arasında olduğu görülmektedir. Katılımcıların \% 26,5'inin meslekteki kıdemi 6 ile 10 yıl arasındadır. Bu durumda meslekteki kıdemi 1 ile 5 yıl arasında olanların lisansüstü öğrenime istekli oldukları söylenebilir. Meslekteki kıdemi 1 ile 5 yıl arasında olanların genelde genç katılımcılar olduğu düşünülürse meslekte yeni olanların kendilerini geliştirmeye ve ilerlemeye daha istekli olduğu söylenebilir. Katılanların \% 86.7'si öğretmen, \% 10.6's1 yönetici ve \% 2.7'si müfettiştir. Bu sonuçtan öğretmenlerin lisansüstü öğrenime daha istekli oldukları söylenebilir. Bunun nedeni olarak öğretmenlerin genelde yarım gün çalışmaları ve görevde yükselme istekleri gösterilebilir. Öğretmenler yarım gün çalıştıkları için lisansüstü öğrenimlerine daha fazla zaman ayırabilmektedir. Ayrıca öğretmenlerin yöneticiliği ve müfettişliği görevde yükselme kademesi olarak gördükleri için bu kademelere ulaşmak için lisansüstü öğrenime devam ettikleri söylenebilir.

Araştırmaya katılan 113 kişiden \% 60.3'ü Ankara Üniversitesi'nde \% 21.2'si Gazi Üniversitesi'nde, \% 8.8'i Hacettepe Üniversitesi'nde ve \% 9.7'si ODTÜ'de kayıtlıdır. Öğretmen, Yönetici ve müfettişler daha çok Ankara Üniversitesi'nde yoğunlaşmaktadır. $\mathrm{Bu}$ durumda Üniversitelerin aldıkları öğrenci sayısı önem taşımaktadır. Örneğin Eğitim Yönetimi ve Teftişi Alanında Hacettepe Üniversitesi ve ODTÜ'de her dönemde bir veya iki öğrenci alırken bu sayı Ankara Üniversitesi'nde her dönemde 10 öğrencidir. Ayrıca ODTÜ ve Hacettepe Üniversitesi'nin eğitim dilinin İngilizce olması öğrencilerin bu üniversiteleri tercih etmemesine neden olabilmektedir. 
Katılımcıların Eğitim Yönetimi ve Teftişi Programında yoğunlaştığı görülmektedir. Katılımcıların \% 40.6'sı Eğitim Yönetimi Teftişi Programına kayıtlıdır. Yine katılımcıların 20.4'ü Eğitim Yönetimi Teftişi Ekonomisi ve Planlaması (EYTEP) programını, \% 8.8'i Eğitimde Ölçme ve Değerlendirme ve Eğitim Bilimleri alanlarını, \% 7.1'i Rehberlik ve Psikolojik Danışmanlık programına kayıtlıdır. Bunu \% 5.3'le Eğitim Programları ve Öğretimi, \% 2.7 ile Yetişkin Eğitimi, \% 1.8 ile Eğitim Ekonomisi ve Planlaması, Eğitimde Program Geliştirme ve Eğitim Psikolojisi programları izlemektedir. Eğitimin Sosyal ve Tarihi Temelleri Programı \% 0.9 ile son sirada yer almaktadır. Bu sonuçlardan öğretmen, yönetici ve müfettişlerin çoğunun Eğitim Yönetimi ve Teftişi Programında yoğunlaştığı söylenebilir. Bu durum Eğitim Yönetimi ve Teftişi Programının katılımcıların meslekleriyle daha yakından ilgili olduğu veya katılımcıların bu programa devam etmekteki asıl amaçlarının yönetici ya da müfettiş olmayı istemeleri şeklinde yorumlanabilir.

\section{Veri Toplama Aracı}

Araştırmada Ankara'da Eğitim Bilimleri alanında lisansüstü öğrenim görmekte olan öğretmen, yönetici ve müfettişlerin sorunlarını saptamak amacıyla araştırmacı tarafından bir anket formu geliştirilmiştir. Anket formu alanyazın taramasından sonra, kaynak kişilerin görüşlerini belirtebilecekleri anket taslağı şeklinde hazırlanmıştır. Anket taslağının içerik geçerliliği için anket uzman görüşüne sunularak, uzmanların görüş ve önerileri doğrultusunda anket maddeleri geliştirilmiştir. Anket formu iki bölümden oluşmaktadır. Birinci bölümde katılımcılar ile ilgili kişisel bilgilere yer verilmiştir. Anketin ikinci bölümünde müfettiş, okul yöneticisi ve öğretmenlerin lisansüstü öğrenimlerini sürdürürken karşılaştıkları lisansüstü programlara, bağlı bulundukları kurumlara ve sosyal ve kişisel faktörlere ilişkin sorunlara ilişkin sorulara yer verilmiştir.

Anket beşli likert dereceleme ölçeği şeklinde hazırlanmıştır. Ölçekte (1) Hiç Katılmıyorum, (2) Çok Az Katılıyorum, (3) Biraz/Orta Katılıyorum, (4) Büyük Ölçüde Katılıyorum, (5) Tamamen Katılıyorum ifadeleri yer almıştır.

Aracın maddelerinin anlaşılır olup olmadığının anlaşılması için ön uygulamaya yapılmıştır. Ön uygulama sonucunda elde edilen veriler doğrultusunda faktör analizi uygulanmıştır. Güvenirlik çalışmaları için, Cronbach Alpha güvenirlik katsayısı kullanılmıştır. Ölçeğin birinci alt boyutu olan "Lisansüstü Eğitim Kurumlarından Kaynaklanan Sorunlar" alt ölçeğinde yer alan maddelerin faktör yük değerlerinin .52 ile .89 arasında değiştiği, tek faktörün toplam varyansın \% 64,02'sini açıkladığı ve Cronbach Alpha güvenirlik katsayısın $\alpha=.89$ olduğu belirlenmiştir. 
Ölçeğin ikinci alt boyutu olan "Bakanlık ve Okuldan Kaynaklanan Sorunlar" alt ölçeğinde yer alan maddelerin faktör yük değerlerinin .46 ile .90 arasında değiştiği, tek faktörün toplam varyansın \% 75,14'ünü açıkladığı ve Cronbach Alpha güvenirlik katsayısın $\alpha=.80$ olduğu belirlenmiştir.

Ölçeğin üçüncü alt boyutu olan "Sosyal ve Ekonomik Faktörlerden Kaynaklanan Sorunlar" alt ölçeğinde yer alan maddelerin faktör yük değerlerinin .81 ile .91 arasında değiştiği, tek faktörün toplam varyansın \% 81.25 'ini açıkladığ 1 ve Cronbach Alpha güvenirlik katsayısın $\alpha=.78$ olduğu belirlenmiştir. Bütün bu sonuçlara göre alt ölçeklerin iç tutarlığa sahip olduğu kabul edilmiştir.

\section{Verilerin Çözümlenmesi}

Araştırmada toplanan verilerin çözümlenmesinde Sosyal Bilimleri İçin İstatistik Paket Programı (SPSS) kullanılmıştır. Verilerin çözümlenmesinde frekans, yüzde, aritmetik ortalama gibi betimsel istatistiklerden yararlanılmıştır.

Araştırma öğretmen, yönetici ve müfettişlere uygulanmış ancak yönetici ve müfettiş boyutunda ulaşılan kişi sayısı oldukça azdır. Bu nedenle, analizlerde karşılaştırma yapabilmek için yönetici ve müfettişler bir grupta toplanmış ve öğretmen ve yönetici olarak ele alınmıştır. Aynı şekilde katılımcıların kayıtlı oldukları programın adına göre karşılaştırma yapabilmek için Eğitim Yönetimi ve Teftişi, Eğitim Ekonomisi ve Planlaması, Eğitim Yönetimi Teftişi Ekonomisi Planlaması ve Yetişkin Eğitimi programları Eğitim Yönetimi, Teftişi, Ekonomisi ve Planlaması (EYTEP); Eğitimde Program Geliştirme, Eğitim Programları ve Öğretimi ve Eğitimin Sosyal ve Tarihi Temelleri programları Eğitim Programları Öğretimi (EPÖ); Eğitim Psikolojisi, Rehberlik ve Psikolojik Danışmanlık ve Eğitim Bilimleri programları Eğitimde Psikolojik Hizmetler (EPH) olarak gruplandırılmış ve analizler bu gruplandırmalara göre yapılmıştır.

Öğretmen, yönetici ve müfettişlerin lisansüstü öğrenimleri sırasındaki karşılaştıkları sorunlara ilişkin görüşlerinin belirlenmesinde aritmetik ortalama $(\overline{\mathrm{X}})$ ve standart sapma (ss) değerleri bulunmuş ve bu ortalamalar değerlendirilmiştir. $\mathrm{Bu}$ değerlerin katılımcıların cinsiyetine göre farklılık gösterip göstermediğine ilişkisiz t-testi, görevlerine göre farklılık gösterip göstermediğine Mann Whitney $U$ testi, yaş, kıdem, üniversite ve öğrenim görülen alana göre farklılık gösterip göstermediğine tek yönlü ANOVA ile bakılmıştır. Farkın anlamlı çıkması durumunda ise farkın hangi gruplardan kaynaklandığını belirlemek amacıyla LSD çoklu karşılaştırma testi uygulanmıştır. Manidarlık sınamalarında anlamlılık düzeyi olarak $\alpha=0.05$ alınmıştır. 


\section{BULGULAR VE YORUM}

"Lisansüstü Öğretim Kurumları Ve Programlardan Kaynaklanan Sorunlar" boyutunda katılımcıların görüşlerine ilişkin ifadelerinin ortalama, standart sapma ve sira değerleri Çizelge 1'de sunulmuştur.

Çizelge 1. Lisansüstü öğretim kurumlarl ve programlardan kaynaklanan sorunlar boyutuna iliskin ifadelerin ortalama, standart sapma ve puan stralart

\begin{tabular}{|c|c|c|c|c|}
\hline $\begin{array}{l}\text { M. } \\
\text { No }\end{array}$ & eler & $\bar{X}$ & $\mathbf{S}$ & $\begin{array}{l}\text { Puan } \\
\text { Sirast }\end{array}$ \\
\hline $\mathbf{1}$ & $\begin{array}{l}\text { Dersler mesai saatleri içinde yer aldığından derslere devam } \\
\text { etmekte zorlanıyorum. }\end{array}$ & 3,55 & 1,28 & 2,5 \\
\hline 2 & Programdan mezun olmak için gereken kredi sayısı fazladır. & 2,96 & 1,40 & 7 \\
\hline 3 & Derslerde verilen ödevler fazla zamanımı almaktadır. & 3,63 & 1,09 & 1 \\
\hline 4 & $\begin{array}{l}\text { Derslerde verilen ödevlerin yoğunluğu nedeniyle istediğim } \\
\text { nitelikte ödev yapamıyorum. }\end{array}$ & 3,53 & 1,25 & 4 \\
\hline 5 & $\begin{array}{l}\text { Derslerde öğrendiklerim alandaki bilgi birikimime katk1 } \\
\text { sağlamıor. }\end{array}$ & 1,85 & 1,10 & 22 \\
\hline 6 & Derslerde yetişkin eğitiminin özellikleri dikkate alınmıyor. & 2,61 & 1,33 & 8 \\
\hline 7 & Derslerde aktif ögrenmeye yer verilmiyor. & 2,57 & 1,32 & 9 \\
\hline 8 & $\begin{array}{l}\text { Derslerin amaçlarını içeren bir ders planı dönem başında } \\
\text { öğrencilere verilmiyor. }\end{array}$ & 2,07 & 1,25 & 19 \\
\hline 9 & $\begin{array}{l}\text { Dersi veren öğretim elemanları ders saatinde bulunamayacağı } \\
\text { durumları önceden haber vermiyor. }\end{array}$ & 2,28 & 1,45 & 14,5 \\
\hline 10 & $\begin{array}{l}\text { Dersle ilgili ana ve yardımcı kaynaklar dönem başında } \\
\text { önerilmemektedir. }\end{array}$ & 1,79 & 1,17 & 21 \\
\hline 11 & Derslerin içeriği beklentilerimi karşılamıyor. & 2,28 & 1,18 & 14,5 \\
\hline 12 & $\begin{array}{l}\text { Dönem başında öğrencilere ölçme ve değerlendirme ölçütleri } \\
\text { açılanmıyor. }\end{array}$ & 2,10 & 1,16 & 18 \\
\hline 13 & $\begin{array}{l}\text { Yapılan sınavlardan sonra, sınav sonucu ile ilgili öğrencilere geri } \\
\text { bildirim verilmiyor. }\end{array}$ & 2,56 & 1,38 & 10 \\
\hline 14 & Değerlendirmede yalnız sınavlara ağırlık veriliyor. & 2,05 & 1,16 & 20 \\
\hline 15 & $\begin{array}{l}\text { Öğrenci- öğretim elemanı arasında etkili bir iletişim } \\
\text { sağlanmamaktadır. }\end{array}$ & 2,46 & 1,20 & 12,5 \\
\hline 16 & $\begin{array}{l}\text { Danışmanım dönem başında seçilecek derslerle ilgili yeterli bilgi } \\
\text { vermiyor. }\end{array}$ & 2,46 & 1,34 & 12,5 \\
\hline 17 & Danışmanım bana gerekli zamanı ayırmıyor. & 2,24 & 1,27 & 16 \\
\hline 18 & Danışmanıma ulaşmakta zorluk çekiyorum. & 2,23 & 1,32 & 17 \\
\hline 19 & Kütüphane kaynak açısından yetersizdir. & 2,97 & 1,57 & 6 \\
\hline 20 & Kütüphaneden ödünç kitap alamıyorum. & 2,49 & 1,63 & 11 \\
\hline 21 & $\begin{array}{l}\text { Kütüphanenin çalışma saatleri mesai saatleri ile sınırlı } \\
\text { olduğundan kütüphaneden yararlanamıorum. }\end{array}$ & 3,50 & 1,65 & 5 \\
\hline 22 & Kütüphane olanaklarına elektronik ortamda ulaşamıyorum. & 3,55 & 1,28 & 2,5 \\
\hline
\end{tabular}


Çizelge 1 incelendiğinde öğretmen yönetici ve müfettişlerin lisansüstü öğretim programlarından kaynaklanan sorunlara ilişkin görüşlerinin puan ortalamalarının $\bar{X}=1.79$ ile $\bar{X}=3.63$ arasında değiştiği görülmektedir. Verilen 22 madde puan sırasına göre incelendiğinde ilk beş madde "Dersler mesai saatleri içerisinde yer aldığından derslere devam etmekte zorlanıorum" ( $\bar{X}=3.55)$, "Derslerde verilen ödevler fazla zamanımı almaktadır" ( $\bar{X}=3.63)$, "Derslerde verilen ödevlerin yoğunluğu nedeniyle istediğim nitelikte ödev yapamıyorum” ( $\bar{X}=3.53$ ), “ Kütüphanenin çalışma saatleri mesai saatleri içerisinde yer aldığından kütüphaneden yararlanamıorum" ( $\overline{\mathrm{X}}=3.50$ ), ve "Kütüphane olanaklarına elektronik ortamda ulaşamıyorum" ( $\overline{\mathrm{X}}=3.55$ ) maddeleridir. Katılımcılar bu maddelere "çok katılıyorum" cevabını vermişlerdir. Bu durum katılımcıların ders saatleri, derslerde verilen ödevler ve kütüphane çalışma saatleri ile ilgili sorun yaşadığını göstermektedir. Verilen 22 madde puan sırasına göre incelendiğinde son beş madde "Derslerde öğrendiklerim alandaki bilgi birikimime katkı sağlamıyor" ( $\bar{X}=1,85)$, "Değerlendirmede sadece sınavlara ağırlık veriliyor" $(\bar{X}=2,05), \quad$ "Derslerin amaçlarını içeren bir ders planı dönem başında öğrencilere verilmiyor" ( $\bar{X}=2,07$ ), "Dönem başında öğrencilere ölçme değerlendirme ölçütleri açıklanmıyor" $(\bar{X}=2,10)$ ve "Danışmanıma ulaşmakta zorluk çekiyorum" ( $\bar{X}=2,23$ ) maddeleridir. Katılımcılar bu maddelere "az katılıyorum" cevabını vermişlerdir. $\mathrm{Bu}$ maddeler incelendiğinde katılımcıların derslerin içeriği, derslerle ilgili ölçme ve değerlendirme ölçütleri ve danışmanlık konularında çok az sorun yaşadığını ortaya çıkmaktadır.

Katılımcıların sorun olarak görmedikleri tek madde "derslerle ilgili ana ve yardımcı kaynaklar dönem başında önerilmemektedir" (madde 10) maddesidir. Bu maddenin ağrllıklı aritmetik ortalaması $\bar{X}=1.79$ 'dur. $\mathrm{Bu}$ ortalama değeri "hiç katılmıyorum" değerlendirme derecesinin üst sınırıdır. $\mathrm{Bu}$ durum aslında katılımcıların bu konuda az da olsa sorun yaşadığ şeklinde yorumlanabilir.

Lisansüstü öğretim programlarından kaynaklanan sorunlar yaş, cinsiyet, kıdem, görev, üniversite ve öğrenim görülen alan değişkenleri açısından incelendiğinde; yaş ve cinsiyet değişkenine göre öğretmen, yönetici ve müfettişlerin görüşleri açısından anlamlı bir fark bulunmamaktadır. Kıdem değişkenine göre yapılan analiz sonuçlarına göre öğretmen, yönetici ve müfettişlerin lisansüstü öğretim kurumları ve programlarından kaynaklanan sorunlara ilişkin görüşleri arasında anlamlı bir fark [F(3-109)=3.34; $\mathrm{p}<0,05]$ vardır. Farkın hangi gruplar arasında olduğunu saptamak amaciyla yapılan 
LSD testi sonuçlarına göre; meslekteki kıdemi bir yıldan az $(\bar{X}=46.81)$ olan öğretmen yönetici ve müfettişlerin, meslekteki kıdemi 6-10 yıl ( $\overline{\mathrm{X}}=$ 17.57) ve meslekteki kıdemi 11 yıl ve üzeri ( $\bar{X}=63.25$ ) olan öğretmen, yönetici ve müfettişlere göre daha az sorun yaşadığı ortaya çıkmıştır.

Görev değişkenine göre yapılan analiz sonuçlarına göre lisansüstü programlardan kaynaklanan sorunlara ilişkin katılımcıların görüşleri görevlerine göre anlamlı bir fark göstermemektedir [U=733,50; $p>0,05]$. Bu durum araştırmaya katılan öğretmen ve yöneticilerin lisansüstü öğretim kurumlarından kaynaklanan yaşadığı sorunlar arasında fark olmadığını ortaya koymaktadır. Lisansüstü Öğretim Programları her öğrenciye aynı şartlarla uygulandığ1 için öğretmen, yönetici ve müfettişlerin bu boyutta benzer sorunları yaşadığı düşünülebilir.

Üniversite değişkenine göre yapılan analiz sonuçlarına göre öğretmen, yönetici ve müfettişlerin lisansüstü eğitim programlarından kaynaklanan sorunlara ilişkin görüşleri arasında anlamlı bir fark $[\mathrm{F}(3-109)=5.01 ; \mathrm{p}<0,05]$ vardır. Farkın hangi üniversiteler arasında olduğunu saptamak amacıyla yapılan LSD testi sonuçlarına göre, Ankara Üniversitesi'ne $(\bar{X}=61.80)$ kayıtlı öğretmen yönetici ve müfettişlerin, Gazi Üniversitesi ( $\bar{X}=56.08)$, Hacettepe Üniversitesi ( $\bar{X}=49.20)$ ve ODTÜ'de $(\bar{X}=45.36)$ kayitlı öğretmen, yönetici ve müfettişlere göre daha fazla sorun yaşadığ çıkmıştır. Ankara Üniversitesi'ne kayıtlı öğretmen, yönetici ve müfettişler derslere devam etmekte daha fazla sorun yaşamaktadır. Bunun nedeni lisansüstü derslerinin mesai saatleri içerisinde yer alması olabilir. Örneğin 2006 - 2007 öğretim yılının I. Döneminde Eğitim Yönetimi ve Teftişi Yüksek lisans programında açılan yedi dersin 6'sı doktora programında açılan 5 dersin 3'ü mesai saatleri içersindedir. Aynı şekilde II. Dönem Ölçme ve Değerlendirme yüksek lisans programında açılan 10 dersin 9'u mesai saatleri içerisindedir. Ayrıca Ankara Üniversite'sinde kütüphane çalışma saatleri ile ilgili olarak daha fazla sorun yaşanmaktadır. Ankara Üniversite'sinde kütüphane çalışma saatleri mesai saatleri ile sınırlıyken, ODTÜ'de kütüphane hafta içi saat 09.00-21.00, hafta sonu 09.00-18.00 saatleri arasında açıktır.

Öğrenim görülen alan değişkenine göre yapılan analiz sonuçlarına göre öğretmen, yönetici ve müfettişlerin devam ettikleri lisansüstü programın adına göre eğitim programlarından kaynaklanan sorunlara ilişkin görüşleri arasında anlamlı bir fark $[\mathrm{F}(2-110)=6.21 ; \mathrm{p}<0,05] \quad$ vardır. Farkın hangi programlar arasında olduğunu saptamak amaciyla yapılan LSD testi sonuçlarına göre, Eğitimde Psikolojik Hizmetler programına kayıtlı $(\overline{\mathrm{X}}=$ 67.80) öğretmen, yönetici ve müfettişlerin, Eğitim Yönetimi, Teftişi, 
Ekonomisi ve Planlaması ( $\bar{X}=57.05$ ) ve Eğitim Programları ve Öğretimi ( $\overline{\mathrm{X}}=50.63$ ) programlarına kayıtlı öğretmen, yönetici ve müfettişlere göre daha fazla sorun yaşadığ 1 ortaya çıkmıştır. Ankara Üniversitesi 2006 -2007 öğretim yılı II. Dönem EPH Yüksek Lisans ders programları incelendiğinde bu program bünyesinde açılan 11 dersin 9'unun mesai saatleri içerisinde yer aldığı görülmüştür. Aynı şekilde doktora ders programı incelendiğinde açılan 8 dersin 7'si mesai saatleri içerisinde olduğu görülmektedir. Bu durumda katılımcıların derslere devam etmesi güçleşmektedir.

Araştırmaya katılan kişilerin "Bakanlık ve Okuldan Kaynaklanan Sorunlar" boyutuna ilişkin ifadelerinin ortalama, standart sapma ve sira değerleri Çizelge 2'de sunulmuştur.

Çizelge 2 incelendiğinde öğretmen yönetici ve müfettişlerin lisansüstü eğitim programlarından kaynaklanan sorunlara ilişkin görüşlerinin puan ortalamalarının $\bar{X}=2.56$ ile $\bar{X}=4.14$ arasında değiştiği görülmektedir. Verilen sekiz madde incelendiğinde ilk üç madde "MEB tayinimi lisansüstü öğenim hakkı kazandığım şehre yapmıyor" ( $\bar{X}=3,92)$, "Öğretmen, yönetici ve müfettişlerin lisansüstü öğrenimi ile ilgili atama ve yer değiştirme mevzuatı yetersizdir" ( $\bar{X}=4,07)$, "Çalışma arkadaşlarımın lisansüstü eğitim yapmam konusundaki olumsuz görüşleri beni rahatsız ediyor" $(\bar{X}=4,14)$, maddeleridir. Katılımcılar bu maddelere "çok katıllyorum" cevabı vermişlerdir. Bu durum katılımcıların atama ve yer değiştirme mevzuatı ve çalışma ortamında sorun yaşadığını göstermektedir.

Çizelge 2 incelendiğinde öğretmen yönetici ve müfettişlerin lisansüstü eğitim programlarından kaynaklanan sorunlara ilişkin görüşlerinin puan ortalamalarının $\bar{X}=2.56$ ile $\bar{X}=4.14$ arasında değiştiği görülmektedir. Verilen sekiz madde incelendiğinde ilk üç madde "MEB tayinimi lisansüstü öğenim hakkı kazandığım şehre yapmıyor" ( $\bar{X}=3,92)$, "Öğretmen, yönetici ve müfettişlerin lisansüstü öğrenimi ile ilgili atama ve yer değiştirme mevzuatı yetersizdir" ( $\bar{X}=4,07)$, "Çalışma arkadaşlarımın lisansüstü eğitim yapmam konusundaki olumsuz görüşleri beni rahatsız ediyor" $(\bar{X}=4,14)$, maddeleridir. Katılımcılar bu maddelere "çok katılıyorum" cevabı vermişlerdir. Bu durum katılımcıların atama ve yer değiştirme mevzuatı ve çalışma ortamında sorun yaşadığını göstermektedir. 
Çizelge 2. Bakanlı ve okuldan kaynaklanan sorunlar boyutuna ilişkin ifadelerin ortalama, standart sapma ve puan siralart

\begin{tabular}{|c|c|c|c|c|}
\hline M. No & Maddeler & $\bar{X}$ & SS & $\begin{array}{l}\text { Puan } \\
\text { strast }\end{array}$ \\
\hline 23 & $\begin{array}{l}\text { Derslere devam edebilmek için izin almada problem } \\
\text { yaşıyorum. }\end{array}$ & 3,60 & 1,60 & 4 \\
\hline 24 & $\begin{array}{l}\text { Okul Müdürü ders programımı lisansüstü } \\
\text { öğrenimime devam edebileceğim şekilde } \\
\text { hazırlanmasına yardımcı olmuyor. }\end{array}$ & 3,31 & 1,44 & 6 \\
\hline 25 & $\begin{array}{l}\text { MEB Lisansüstü öğrenime gereken kolaylığ } 1 \\
\text { göstermiyor. }\end{array}$ & 2,87 & 1,50 & 7 \\
\hline 26 & $\begin{array}{l}\text { MEB tayinimi lisansüstü öğrenim hakkı kazandığım } \\
\text { şehre yapmıyor. }\end{array}$ & 3,92 & 1,29 & 3 \\
\hline 27 & $\begin{array}{l}\text { Öğretmen, yönetici ve müfettişlerin lisansüstü } \\
\text { öğrenimi ile ilgili izin mevzuatı yetersizdir. }\end{array}$ & 3,39 & 1,57 & 5 \\
\hline 28 & $\begin{array}{l}\text { Öğretmen, yönetici ve müfettişlerin lisansüstü } \\
\text { öğrenimi ile ilgili atama ve yer değiştirme mevzuatı } \\
\text { yetersizdir. }\end{array}$ & 4,07 & 1,15 & 2 \\
\hline 29 & $\begin{array}{l}\text { Çalışma arkadaşlarımın lisansüstü eğitim yapmam } \\
\text { konusundaki olumsuz görüşleri beni rahatsız ediyor. }\end{array}$ & 4,14 & 1,09 & 1 \\
\hline 30 & $\begin{array}{l}\text { Çalışma arkadaşlarım lisansüstü öğrenimim } \\
\text { nedeniyle ders programımın düzenlenmesinden } \\
\text { şikâyetçi oluyor. }\end{array}$ & 2,56 & 1,51 & 8 \\
\hline
\end{tabular}

Verilen sekiz madde incelendiğinde son üç madde "Okul Müdürü ders programımı lisansüstü öğrenimime devam edebileceğim şekilde hazırlanmasına yardımcı olmuyor" ( $\bar{X}=3,31)$, "MEB Lisansüstü öğrenime gereken kolaylığı göstermiyor" ( $\bar{X}=2,87)$ ve "Çalışma arkadaşlarım lisansüstü öğrenimim nedeniyle ders programımın düzenlenmesinden şikâyetçi oluyor" ( $\bar{X}=2,56)$ maddeleridir.

Katılımcılar "Okul Müdürü ders programımı lisansüstü öğrenimime devam edebileceğim şekilde hazırlanmasına yardımcı olmuyor" ve "MEB Lisansüstü öğrenime gereken kolaylığı göstermiyor" maddelerine "orta derecede katılıyorum" cevabı vermişlerdir. Bu durum katılımcıların ders programı ve MEB ile ilgili olarak orta derecede sorun yaşadığını ortaya koymaktadır. Burada ortaya çıkan ilginç sonuç katılımcıların derslere devam edebilmek için izin almada problem yaşıyorum maddesine çok katılıyorum cevabı verirken, lisansüstü öğrenim ile ilgili izin mevzuatını yetersiz buluyorum maddesine orta derecede katıliyorum cevabi vermeleridir. $\mathrm{Bu}$ durum aslında öğretmen, yönetici ve müfettişlerin derslere devam etmede problem yaşadığını ancak bu konuyu düzenleyen izin mevzuatı ile ilgi yeterli bilgiye sahip olmadıklarından kaynaklanıyor olabilir. 
Katılımcıların "az katılıyorum" cevabını verdikleri tek madde "Çalışma arkadaşlarım lisansüstü öğrenimim nedeniyle ders programımın düzenlenmesinden şikâyetçi oluyor" maddesidir. Bu sonuç katılımcıların çalışma arkadaşlarının lisansüstü eğitim konusundaki olumsuz görüşlere sahip olduğunu belirtirken bu olumsuz görüşlerin ders programının düzenlenmesinde kolaylık gösterilmesi ile ilgili olmadığını ortaya koymaktadır. Katılımcıların çalışma arkadaşları ders programının düzenlenmesinden şikayetçi değildir. Ancak lisansüstü eğitim konusunda olumsuz görüşlere sahiptir. Bunun nedeni kişilerin lisansüstü eğitim konusunda yeterli bilgiye sahip olmadıklarından ve son zamanlarda yapılan düzenlemelerle lisansüstü eğitimin kişiye maddi bir karşllık vermediği için bu eğitimi gereksiz görmesinden olabilir.

Katılımcıların bakanlık ve okuldan kaynaklanan sorunlara ilişkin görüşleri yaş, cinsiyet, kıdem, görev, üniversite ve öğrenim görülen alan değişkenleri açısından incelendiğinde anlamlı bir fark olmadığı görülmüştür. Analiz sonuçları incelendiğinde öğretmen, yönetici ve müfettişlerin lisansüstü öğrenimleri sırasında bakanlık ve okuldan kaynaklanan sorunlar yaşadığ1 ortaya çıkmıştır. Bu sorunlar, incelenen değişkenler açsından anlamlı bir fark göstermemektedir. Çünkü katılımcıların hepsi MEB'na bağlı devlet memuru statüsündedir ve lisansüstü öğrenim ile ilgili aynı haklara sahiptir. Bu haklar yasalarla düzenlenmektedir. Bu nedenle katılımcılar benzer sorunlar yaşıyor olabilir. Bu sonuçlar Oluk ve Çolak (2005) yapılan araştırma sonuçları ile benzerlik taşımaktadır. $\mathrm{Bu}$ araştırmada da öğretmenlerin lisansüstü öğrenimlerine devam edebilmek için izin almada sorun yaşadıkları ortaya çıkmıştır.

Araştırmaya katılan kişilerin "Sosyal ve Ekonomik Faktörlerden Kaynaklanan Sorunlar" boyutuna ilişkin ifadelerinin ortalama, standart sapma ve sıra değerleri Çizelge 3'te sunulmuştur.

Çizelge 3. Sosyal ve ekonomik faktörlerden kaynaklanan sorunlar boyutuna ilişkin ifadelerin ortalama, standart sapma ve puan stralart

\begin{tabular}{|c|c|c|c|c|}
\hline M. No & Maddeler & $X$ & SS & $\begin{array}{l}\text { Puan } \\
\text { Sirast }\end{array}$ \\
\hline 31 & $\begin{array}{l}\text { Dersler için gerekli olan fotokopi masraflarını } \\
\text { karşılamakta zorlanıyorum. }\end{array}$ & 2,11 & 1,13 & 5 \\
\hline 32 & $\begin{array}{l}\text { Dersler için gerekli olan kitap masraflarını karşılamakta } \\
\text { zorlanıyorum. }\end{array}$ & 2,57 & 1,36 & 4 \\
\hline 33 & $\begin{array}{l}\text { Lisansüstü öğrenim için gereken harç ücretlerini } \\
\text { karşılamakta zorlanıyorum. }\end{array}$ & 2,62 & 1,37 & 3 \\
\hline 34 & $\begin{array}{l}\text { Derslerin yoğunluğundan ailemle ilgilenemediğim için } \\
\text { sorun yasıorum. }\end{array}$ & 3,23 & 1,30 & 2 \\
\hline 35 & $\begin{array}{l}\text { Derslerin yoğunluğundan sosyal etkinliklere katılacak } \\
\text { zamanı bulamıyorum. }\end{array}$ & 3,64 & 1,20 & 1 \\
\hline
\end{tabular}


Çizelge 3 incelendiğinde öğretmen yönetici ve müfettişlerin sosyal ve ekonomik faktörlerden kaynaklanan sorunlara ilişkin görüşlerinin puan ortalamalarının $\bar{X}=2,11$ ile $\bar{X}=3,64$ arasında değiştiği görülmektedir. Verilen beş madde incelendiğinde ilk iki madde "Derslerin yoğunluğundan sosyal etkinliklere katılacak zamanı bulamıyorum." ( $\bar{X}=3.64)$ ve "Derslerin yoğunluğundan ailemle ilgilenemediğim için sorun yasıyorum” ( $\bar{X}=3.23$ ) maddeleridir. Katılımcılar ilk maddeye "çok katılıyorum" ve cevabı verirken diğer maddeye "orta derecede katılıyorum" cevabı vermişlerdir. Bu durum katılımcıların lisansüstü öğrenimde ders yükünün fazla olması nedeniyle sosyal faaliyetlere ve ailelerine zaman ayıramadıklarını ortaya koymaktadır. Benzer bir bulguya da Meydan 1994 yılında yaptığı araştırma sonucunda ulaşmıştır.

Verilen beş madde incelendiğinde son iki madde "Dersler için gerekli olan fotokopi ücretlerini karşılamakta zorlanıyorum" $(\overline{\mathrm{X}}=2,11)$ ve "Dersler için gerekli olan kitap masraflarını karşılamakta zorlanıyorum” ( $\bar{X}=2,57)$ maddeleridir. Katılımcılar bu maddelere az katıldıklarını belirtmişlerdir. Bu durum katılımcıların lisansüstü öğrenim için yaptıkları masrafı karşılamakta zorlanmadığı şeklinde yorumlanabilir.

Katılımcıların sosyal ve ekonomik faktörlerden kaynaklanan sorunlara ilişkin görüşleri yaş, cinsiyet, kıdem, görev, üniversite ve öğrenim görülen alan değişkenleri açısından incelendiğinde anlamlı bir fark olmadığ görülmüştür. Araştırmanın bu boyutunda çıkan temel bulgu lisansüstü öğrenim görmekte olan öğretmen, yönetici ve müfettişlerin sosyal etkinliklere katılacak zaman bulmada sorun yaşadığ 1 ve bu sorunun değişkenlere göre anlamlı bir fark göstermediğidir. Ancak Ankara Üniversitesi'ne kayıtlı katılımcılar, verilen ödevlerin diğer üniversitelerde kayıtlı katılımcılara göre daha fazla zamanlarını aldığını belirtirken dört üniversitedeki katılımcılar da sosyal etkinliklere katılacak zaman bulamadıklarını belirtmişlerdir. Bu durum diğer üniversitelerdeki katılımcıların sosyal etkinliklere katılacak zamanı bulamamasının nedeni olarak lisansüstü öğrenimlerini gördüklerini ancak bu öğrenimlerinin aslında çok fazla zamanlarını almadığı şeklinde yorumlanabilir.

\section{SONUÇ VE ÖNERILER}

Araştırmanın bulgularına dayalı olarak lisansüstü eğitim programlarından kaynaklanan sorunların oldukça fazla olduğu görülmüştür. $\mathrm{Bu}$ sorunları Ankara Üniversitesi'ne kayıtlı katılımcıların daha fazla yaşadığı görülmektedir. Bu sorunlardan başlıcaları verilen ödevlerin fazla olması ve bu nedenle istenilen nitelikte ödev yapılamamas1, ders saatlerinin 
mesai saatleri içinde yer alması nedeni ile derse devam etmede yaşanan zorluklar ve kütüphanenin mesai saatleri içinde açık olması nedeni ile kütüphaneden yeterince yararlanamamalarıdır. Ayrıca katılımcılar programdan mezun olmak için gereken kredi sayısını fazla bulmakta ve danışmanlarına ulaşmada zorluk çekmektedirler.

Araştırmada ortaya çıkan Bakanlık ve okuldan kaynaklanan sorunlar katılımcıların çalışma arkadaşlarının lisansüstü eğitim konusundaki olumsuz düşüncelerinden rahatsız olması, öğretmen, yönetici ve müfettişlerin lisansüstü öğrenimi ile ilgili atama ve yer değiştirme mevzuatı ve izin mevzuatı yetersiz görülmesidir. Araştırmada sosyal ve ekonomik faktörlerden kaynaklanan sorunlar olarak katılımcıların derslerin yoğunluğu nedeniyle sosyal etkinliklere katılacak zaman bulamadığı ve aileleriyle yeteri kadar ilgilenemediği ortaya çıkmıştır.

Ortaya çıkan bu sorunları çözmek için öncelikle lisansüstü eğitim dersleri mümkün olduğunca çalışanların devam edebileceği saatlere özellikle de akşam saatlerine konulmalıdır. Ayrıca öğretmen, yönetici ve müfettişlere lisansüstü eğitim derslerine devam edebilmeleri için ilgili izin mevzuatına konu ile ilgili öğretmen, yönetici ve müfettişlerin izin almasını kolaylaştıracak açık ve net bir madde konulmalı ve bu durum bir üst amirin takdirine bırakılmamalıdır. Öğretmenlerin ders programları lisansüstü eğitimlerine devam edebilecek şekilde düzenlenmeli gerekirse lisansüstü eğitimlerine devam edebilmeleri için okuldaki haftalık ders yükü azaltılmalıdır. Ayrıca öğretmen, yönetici ve müfettişlerin derslere devam etmede yaşadıkları sorun nedeniyle lisansüstü eğitimdeki ders aşamasını bitirme süresinde esneklik tanınması da sorunu çözmede yardımcı olabilir.

Öğretmen, yönetici ve müfettişler, sadece mesai saatleri içerisinde açık olduğundan kütüphaneden yeteri kadar yararlanamamaktadır. $\mathrm{Bu}$ nedenle kütüphane akşam saatlerinde de açık olmalı ve hafta sonu en azından bir gün öğrencilerin hizmetinde olmalıdır. Ayrıca kütüphane olanaklarına elektronik ortamda ulaşılabilmesi için üniversiteler gerekli çalışmaları yapmalı ve öğrencileri bu konuda bilgilendirmelidir. Öğrencilerin kütüphaneden ödünç alabileceği kitap sayısı artırılmalı ve ödünç kitap alma süresi uzatılmalıdır.

Araştırma sonuçlanı, danışmanlık hizmeti ve derslerin işlenişi ile ilgili sorunlar olduğunu ortaya koymuştur. Öncelikle danışmanlar dönem başında öğrencilere ders seçimiyle ilgili bilgileri vermelidir. Gerekirse üniversitelerin ilgili birimleri bu konuyu açıklayan bir kitapçık hazırlayıp öğrencilere dağıtmalıdır. Öğrenciler danışmanlarına ulaşmakta sorun yaşamaktadırlar. $\mathrm{Bu}$ sorunu çözmek için zaten yasal olarak danışmanlık hizmeti olarak ayrılması gereken, haftada bir gün belirli saat aralığı, öğrenci ile birlikte karşılıklı olarak ayarlanmalıdır. Ayrılan bu zamanda danışman mutlaka yerinde bulunmalidir. 
Araştırma sonucunda lisansüstü öğrenim gören öğretmen, yönetici ve müfettişlerin derslerdeki ölçme ve değerlendirme ölçütleri, ders işlenişi ve dersi veren öğretim elemanları ile ilgili sorun yaşadığı ortaya çıkmıştır. Dersi veren öğretim elemanı dersle ilgili ölçme ve değerlendirme ölçütlerini dönem başında öğrencilere açıklamalı, dersleri değerlendirmede sadece sınavlara ağırlık verilmemeli, öğrencilerin dönem içerisinde sergiledikleri performanslar da değerlendirmelidir. Lisansüstü eğitime devam eden kişilerin konumları ve yaşları düşünülerek derslerde yetişkin eğitiminin özellikleri dikkate alınmalı ve ders işlerken öğrencilerin aktif olarak derse katılmaları sağlanmalıdır. Araştırmaya katılan öğrencilerin derslere oldukça zor koşullar altında devam etmeye çalıştığı göz önünde bulundurularak öğretim elemanları derslere gelemeyeceği durumları mümkün olduğunca önceden haber vermelidir. Derslerde gerekli çalışmalar yapılarak öğrencilerin derslerden ne beklediği açıkça ortaya koyulmalı ve ders içerikleri yeniden düzenlenmelidir.

Araştırma sonuçlarında programdan mezun olmak için gereken kredi sayısının fazla olduğu belirlenmiştir. Ancak dört üniversite incelendiğinde mezun olmak için gereken kredi sayısının benzer olduğu ve zorunlu derslerle kredi sayısının neredeyse tamamlandığ 1 görülmüştür. $\mathrm{Bu}$ nedenle kredi sayısını azaltmak yerine özellikle tam zamanlı çalışanlar için lisansüstü eğitimi bitirme süresinde esneklik tanınmalıdır.

Araştırma sonucunda lisansüstü öğrenim gören öğretmen, yönetici ve müfettişlerin mevzuatla ilgili sorunları olduğu saptanmıştır. Öğretmen, yönetici ve müfettişlerin atama ve yer değiştirme mevzuatı yeniden düzenlenmeli, lisansüstü öğrenim gören öğretmen, yönetici ve müfettişler zorunlu hizmetten muaf tutulmalı ve atamalarının öğrenim gördükleri yere yapılması için öncelik tanınmalıdır.

MEB ve YÖK işbirliği ile öğretmen, yönetici ve müfettişler alanında veya eğitim bilimleri alanında lisansüstü öğrenim görmek koşulu ile lisansüstü eğitim için gerekli olan harç ücretinden muaf tutulmalıdır.

\section{KAYNAKLAR}

Acar, H. (2002), Eğitim Yöneticileri Nasıl Yetiştirilmeli? 21. Yüzyıl Eğitim Yöneticilerinin Yetiştirilmesi Sempozyumu, Ankara: Ankara Üniversitesi Basımevi, 313 - 326.

Acar,H (2002a), 21. Yüzyıla Girerken Milli Eğitim Bakanliğı'nda Eğitim Yöneticilerinin Yetiştirilmesi ve Geliştirilmesinde Yeni Yaklaşımlar, 21. yüzyıl Eğitim Yöneticilerinin Yetiştirilmesi Sempozyumu, Ankara: Ankara Üniversitesi Basımevi, 179 - 193. 
Arıcı, H. (2001), Sosyal Bilimler Alanında Bilim Adamı Yetiştirme: Lisansüstü Eğitim, Bilim Adamı Yetiştirme Lisansüstü Eğitim, Ankara: TÜBA Bilimsel Toplantı Serileri:7, 53 - 62

Ataünal, A (2002), Bilim ve Eğitimde Görevli Kuruluşların İslevleri ve İşbirliği (Milli Ĕgitim Bakanlığ Açısından), Bilim ve Eğitim, Ankara, TÜBA Bilimsel Toplantı Serileri:2, $151-156$.

Balcı, A ve Çınkır Ş. (2002). Türkiye'de Eğitim Yöneticilerinin Yetiştirilmesi, 21. Yüzyıl Eğitim Yöneticilerinin Yetişstirilmesi Sempozyumu, Ankara: Ankara Üniversitesi Basımevi, 211- 236.

Başer, N., Narl1, S. Ve Günhan, B. (2005). Öğretmenlerin Lisansüstü Eğitim Alanlarında Yaşanan Sorunlar ve Çözüm Önerileri, Lisansüstü Eğitim, Dokuz Eylül Üniversitesi Buca Eğitim Fakültesi Dergisi, Özel Sayı:1, 129-135.

Calderhead, J. (1995). Öğretmenlerin Uzmanlığının Tanınması Geliştirilmesi: 21. Yüzyılı Bekleyen Sorunlar, Uluslar Arası Dünya Öğretmen Ĕgitimi Konferansı, Ankara: Milli Eğitim Bakanlığ1

Çakar, Ö.(2001), Fen Bilimleri Alanında Bilim Adamı Yetiştirme: Lisansüstü Eğitim, Bilim Adamı Yetiştirme Lisansüstü Eğitim, Ankara: TÜBA Bilimsel Toplantı Serileri:7, 65-75

Doğusan, F. (2003). Illkögretim Okulu Yönetici ve Öğretmenlerinin Ögrretmenlerin Lisansüstü Öğrenimi Konusundaki Tutumları, Yüksek Lisans Tezi, Kırıkkale Üniversitesi, Sosyal Bilimler Enstitüsü

Erkan, H. (1998). Bilgi Toplumu ve Ekonomik Gelişme, İstanbul: Türkiye İş Bankası Yayınları

Fındıkçı, İ. (2001). Bilgi Toplumunda Eriyen Değerler ve Eğitim, 2000 Yllında Milli Eğitim Örgütü ve Yönetimi Ulusal Sempozyumu, Ankara: Tekışık Yayınları

Geray, C. (2002). Halk Eğitimi, Ankara, İmaj Yayınevi.

Güven, İ (2001). Öğretmen Yetiştirmenin Uluslar arası Boyutu (UNESCO 45. Uluslar arası Eğitim Kongresi), Milli Eğitim Dergisi, Sayı:150 (yayim.meb.gov.tr/dergiler/Güven.htm. 16.12.2006)

Hersey, P.ve Blanchard, K. (1982). Management of Organizational Behavior, USA: New Jersey: Prentice / Hall International Editions

Karakütük,K.(2000), Öğretmenlerin Lisansüstü Öğretimi Konusunda Yönetici ve Öğretmenlerin Görüşleri, Buca Eğitim Fakültesi Dergisi, İzmir: Dokuz Eylül Üniversitesi Yayınları

Karakütük, K.(2002a), Lisansüstü Öğretimin Sorunları, Eğitim Araştırmaları Dergisi, Say1:7, Ankara: An1 Yayınc1l1k, 65-75.

Karakütük, K.(2002b), Öğretim Üyesi ve Bilim Insanı Yetiştirme Lisansüstü Ögretimin Planlanması, Ankara: Anı Yayıncılık 
Meydan, G. (1994). Ankara Üniversitesi Sosyal Bilimler Enstitüsü’ne Kayttlı Lisansüstü Öğrencilerin Sorunları, Ankara Üniversitesi Sosyal Bilimler Enstitüsü, Yayımlanmamış Yüksek Lisans Tezi.

OECD (1987). Post Graduate Education in the 1980's, France: OECD Publications

Oguz, A. (2004), Bilgi Çağında Yükseköğretim Programları, Milli Eğitim Dergisi, Say1:164, $162-17$.

Oğuzkan, F. (1981). Ĕ̆itim Terimleri Sözlüğü, Ankara: Türk Dil Kurumu Yayınları.

Oluk, S. Ve Çolak, F. (2005). Milli Eğitim Bakanlığı'na Bağlı Okullarda Öğretmen Olarak Çalışan Lisansüstü Öğrencilerinin Karşılaştıkları Bazı Sorunlar, Lisansüstü Eğitim, Dokuz Eylül Üniversitesi Buca Eğitim Fakültesi Dergisi, Özel Say1:1, 141-144.

Özdem G., Bülbül T. Ve Güngör S.(2002). Eğitim Yönetimi Planlamasl Teftişi ve Ekonomisi Anabilim Dall Tezsiz Yüksek Lisans Programına Devam Eden Ögretmen ve Okul Yöneticilerinin Programa ilişkin Görüşlerinin Değerlendirilmesi, 21. yüzyıl Eğitim Yöneticilerinin Yetiştirilmesi Sempozyumu, Ankara : Ankara Üniversitesi Basımevi, 165-177

Özden, Y. (2002). Yükselen Değerler ve Ĕgitim, Ankara: Pegem A Yayıncilik.

Özgüven, İ.E. (1997), Psikolojik Testler, Ankara: Yeni Doğuş Matbaası

Sayan, Y ve Aksu, H. (2005). Akademik Personel Olmadan Lisansüstü Eğitim Yapan Bireylerin Karşılaştıkları Sorunlar Üzerine Nitel Çalışma, Lisansüstü Eğitim, Dokuz Eylül Üniversitesi Buca Eğitim Fakültesi Dergisi, Özel Sayı: 1, 59-66

Schermerhons, J.R. (1996). Management and Organizational Behavior Essentials. Canada: John Willey \& Sons Inc.

Taymaz, H. (2005), Eğitim Sisteminde Teftiş, Ankara: Pegem A Yayıncılık Thomson, S.D. (1992), School Leadership, California: Corwin Press,İnc.

Tosun, İ. (2001), Açılış Konuşması, Bilim Adamı Yetiştirme Lisansüstü Eğitim, Ankara: TÜBA Bilimsel Toplantı Serileri: 7, 7-15

Tuzcu, G. (2003), Lisansüstü Öğretim için Yurtdışına Öğrenci Göndermenin Planlanmas1, Milli Ĕgitim Dergisi, Sayı:160, 314 - 339

Varış,F. (1973), Türkiye'de Lisansüstü Eğitim: Sosyal Bilimlerde, Ankara: Ankara Üniversitesi Yayını, No:34.

ekutup.dpt.gov.tr/eğitim/oik550.pdf (15.12.2006)

www.eurydice.org (01.09.2007).

en.wikipedia.org. (01.09.2007). 